\title{
Ameliorating Effect of Vitamin E on Liver Damage Caused by Administering Tartrazine in Male Mice
}

Turki M. Al-Shaikh*

\author{
Department of Biology, College of Science and Arts at Khulis, University of Jeddah, Jeddah, Saudi Arabia;
} tmalshaikh@uj.edu.sa

\begin{abstract}
Tartrazine is a common artificial food and pharmaceutical additive and has become a part of daily intake values. However, the actual daily intake is much higher than the recommended value. A higher intake is shown to exhibit carcinogenic, mutagenic, and allergic effects. The present work aimed to research whether antioxidant vitamin E (Vit E) therapy would impact liver damage induced by Tartar-Zine (TZ). Twenty-eight mice were used in this experimental study. Mice were categorized into four groups; group (A) in which mice served as control were orally administered distilled water for 28 days. Group (B) in which mice administered daily $100 \mathrm{mg} / \mathrm{kg}$ vitamin E orally for 28 days. Group (C) in which mice administered daily $300 \mathrm{mg} / \mathrm{kg}$ tartrazine dissolved in distilled water orally for 28 days. Group (D), mice received orally both $100 \mathrm{mg} / \mathrm{kg}$ vitamin $\mathrm{E}$ and $300 \mathrm{mg} / \mathrm{kg}$ tartrazine concomitantly for 28 days. Biochemical parameters in serum including liver function enzymes aspartate transaminase (AST), alanine transaminase (ALT) and alkaline phosphatase (ALP), glutathione (GSH), malondialdehyde (MDA), superoxide dismutase (SOD), glutathione S-transferase (GST) and catalase (CAT) had been inspected. Histological and immunological studies were done including Cyclooxygenase-2 (COX-2). Results showed that TZ treatment initiates hepatic disorders indicated by elevation of liver enzymes and oxidative stress markers in treated mice. Oral administration of Vit E diminished the activities of ALP, AST, and ALT compared to treated mice. Besides, Vit E effectively reduced oxidative stress as indicated by elevated GSH, SOD, GST, CAT, and decreased MDA. Histologically, TZ+Vit E delineated moderate potential improvement of hepatic tissue architecture. Immunologically revealed that $\mathrm{TZ}+\mathrm{Vit} \mathrm{E}$ treated mice showed reduction in COX-2 immuno-expression in hepatic cords sinusoids and hepatocytes versus TZ group. In conclusion, treatment with Vit $\mathrm{E}$ could improve all deviated biochemical, immunological, and histological changed induced by tartrazine consumption.
\end{abstract}

Keywords: Hepatoxicity, Tartrazine E102, Vitamin E

\section{Introduction}

Colorants incorporate naturally occurring pigments and manufactured azo colors are generally used to improve food and drink nature in industries ${ }^{1}$, given their drawing in covering properties, variable colors, dependability, and low cost so they are delivered by million consistently ${ }^{2}$. Azo colors get major interest as they can have nephrotoxicity, hepatotoxicity, and neurotoxicity. Besides, late reports showed that azo dyes have oxidative stress $^{3}$, and inflammatory effects ${ }^{1}$. The destructive effects of azo colors were due to fragrant amines conveyed from cleavage of the aryl-N=N-aryl bundle by intestinal microbiota ${ }^{4}$. These aromatic organic amines have toxic, mutagenic, and malignancy effects ${ }^{5}$. Tartrazine (TZ, E102), is one of the most regularly utilized colorants with lemon yellow for industrial and food items, soft drinks, jellies, sauces, chewing gums, cosmetics, and cleaners ${ }^{6}$. Food and Agriculture Organization and World Health Organization (FAO/WHO) recommended daily $\mathrm{TZ}$ admission from

${ }^{*}$ Author for correspondence 
0 to $7.5 \mathrm{mg} / \mathrm{kg}$ body weight ${ }^{7}$. A few kinds of research demonstrated the impact of $\mathrm{TZ}$ in exploratory animals. Association of $700 \mathrm{mg} / \mathrm{kg}$ of TZ set off cell improvement dysregulation and release in the brain of rodents ${ }^{8}$. TZ administration at dose of $50 \mathrm{mg} / \mathrm{kg} /$ day for fourteen days in mice can cause periportal injury of hepatic cells and mild periportal fibrosis ${ }^{9}$. At doses of 10 and $100 \mathrm{mg} / \mathrm{kg} /$ day, TZ induced oxidative damage in the liver and kidney of rodents ${ }^{4}$. Moreover, rodents who got higher dosages of $\mathrm{TZ}(500 \mathrm{mg} / \mathrm{kg})$ for 30 days exhibited rotations in learning and memory and declined cell reinforcement protections ${ }^{10}$. Besides, chronic administration of TZ (7.5 $\mathrm{mg} / \mathrm{kg}$ ) per diet for 90 days led to oxidative pressure and liver injury in grown-up rodents ${ }^{3}$.

Tocopherols are a class of eight types of organic supplement that has Vitamin E activity ${ }^{11}$. In general, vitamin $\mathrm{E}$ is utilized as medication for malignancy ${ }^{12}$, infertility disorders in male ${ }^{13}$, nervous disease ${ }^{14}$, cardiovascular sickness ${ }^{15}$, and improvement in insulin activity $^{16}$.

This experimental study aimed to assess the protective effect of daily intake of vitamin $\mathrm{E}$ on noxious effects due to chronic administration of $\mathrm{TZ}$ on hepatic physiological, histological, and immunological alterations in mice.

\section{Materials and Methods}

\subsection{Chemicals}

Tartrazine (C.I. 19140 CAS No. 1934-21-0) as a yellow azo dye of MW 534.37, synonyms: E102, purchased from Sigma-Aldrich Corp. (St. Louis, MO, USA). The manufacturer assured purity of $86.7 \%$. Vitamins E (DL- $\alpha$ tocopherol acetate) $(500 \mathrm{mg} / \mathrm{ml})$, was purchased from Merck (Germany) as a slightly yellow viscous liquid.

\subsection{Experimental Animal}

A total of twenty-eight adult mice (Mus musculus), aged 12 weeks old and weighed 25-30 g, were obtained from King Fahd Medical Research Center (KFMRC), King Abdul-Aziz University, Saudi Arabia and were used in the following experimental study. All ethical points regarding laboratory handling and treatments were followed as described in the animal care ethics committee of King Abdul-Aziz University and inconsistent with the Guidelines for the Proper Treatment of Laboratory Animals (Canadian Animal Care Council, CACC) ${ }^{17}$.

\subsection{Experimental Design and Grouping}

After acclimatization for one week, the animals were randomly divided into 4 groups, with seven mice each. Control group in which mice served as control were orally administered distilled water for 28 days, Vit E group in which mice administered daily $100 \mathrm{mg} / \mathrm{kg}$ vitamin E orally for 28 days soluble in corn oil ${ }^{18}$. TAZ group in which mice administered daily $300 \mathrm{mg} / \mathrm{kg}$ tartrazine dissolved in distilled water by oral gavages for 28 days ${ }^{6}$. TAZ+Vit E group in which mice received orally both 100 $\mathrm{mg} / \mathrm{kg}$ vitamin $\mathrm{E}$ and $300 \mathrm{mg} / \mathrm{kg}$ tartrazine concomitantly for 28 days.

\subsection{Procedure and Sample Collection}

At the end of $4^{\text {th }}$ weeks treatment and consequently after 24 hours of the last oral administration, the animals were sacrificed through cervical dislocation under ether anesthesia. The blood samples were collected into a plain tube, centrifuged at $3000 \mathrm{rpm}$, and separated sera were frozen immediately $\left(-20^{\circ} \mathrm{C}\right)$ until used.

\subsubsection{Liver Enzymes Bioassay}

Alanine Aminotransferase (ALT), Aspartate Aminotransferase (AST), and ALkaline Phosphatase (ALP) were determined in the sera using commercially available kits for mice according to the manufacture protocol.

\subsubsection{Antioxidant Status}

The oxidative stress markers as malondialdehyde (MDA), reduced Glutathione (GSH), Super-Oxide Dismutase (SOD), catalase and Glutathione S-Transferase (GST) were determined in sera of mice using Bio-diagnostic assay kits according to the manufacturer's instructions

\subsubsection{Histopathological Examinations}

After sacrificing mice within each group, the liver was quickly isolated, rinsed with regular saline then sliced into smaller specimens. The specimens then fixed with formalin, dehydrated at an increasing concentration of ethanol (70\%-100\%), distilled into xylene then eventually integrated with wax paraffin. The liver then cut into 4 $\mu \mathrm{m}$ section using a microtome. The sections then stained with Hematoxylin and Eosin (H\&E) and analyzed under a light microscope. 


\subsubsection{Immunohistochemical Studies}

In liver sections, the expression of cyclooxygenase-2 (COX-2) (RB-9072-P0, Thermo Scientific) among formalin-fixed paraffin-embedded tissues was identified immunohistochemical according to production directives. Blocks are then cut into $4 \mu \mathrm{m}$ thick sections fitted with glass slides, stripped by xylene, rehydrated by graded ethanol. The sections were heated in $10 \mathrm{~mm}$ citrate buffer with $\mathrm{pH} 6.0$ for 10-15 min for antigen recovery in the microwave. They were treated for 10 minutes at room temperature with 3 percent $\mathrm{H}_{2} \mathrm{O}_{2}$ to obstruct endogenous peroxidase. Polyclonal anti-COX-2 slides (1:100, Rabbit $\mathrm{Ab})$ were tested. Parts of IgG anti-mouse were washed, incubated, and stained with streptavidin-peroxidase according to manufacturer instructions. The primary antibody was omitted in negative control slides.

\subsubsection{Statistical Analysis}

The data obtained for each group was expressed as mean \pm Standard Error (SE) and compared using Statistical Processor System Support (SPSS, Chicago, IL) version 16.0. The comparison was made by OneWay Analysis of Variance (OneWay ANOVA) followed by post-hoc-Least Significant Difference analysis (LSD) for comparison between groups. $P$-value $<0.05$ was deemed to be significant and $P<0.001$ as highly significant.

\section{Result}

\subsection{Enzyme Activity}

In the existing work and as regards the control level, the recorded data revealed an insignificant decrease in the activities of all studied enzymes post 28 daily administration of Vit E. In comparison, administration of $\mathrm{TZ}$ at the studied dose level brought about a greater significant increase $(P<0.05)$ in the activity of transaminases (ALT, AST), and ALP in sera of treated animals. Moreover, as in contrast with the TZ-treated mice group, the hepatic enzyme activity in the animal group treated with $\mathrm{TZ}+\mathrm{Vit} \mathrm{E}$ showed a tendency to decrease but the values recorded still significantly higher than the control group (Figure 1).

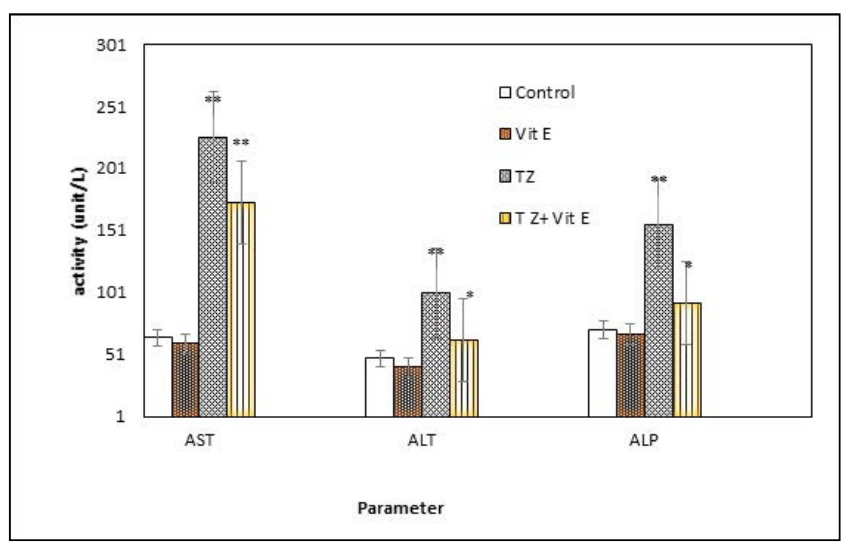

Figure 1. Hepatic enzyme activity in the control and treated groups. Values are represented as mean \pm SE. ALT: alanine aminotransferase, AST: aspartate aminotransferase, and ALP: alkaline phosphatase. The symbols ${ }^{\star} P<0.05,{ }^{* *}: P<0.01$ indicate significant differences.

\subsection{Antioxidant Status}

The animals treated with $\mathrm{TZ}$ showed a decrease in GSH, GST, SOD, and CAT and increased MDA sera levels in contrast with the control group $(P<0.05)$. Moreover, the animal group treated with Vit. E showed higher levels of GSH, GST, and SOD $(P<0.05)$ and lower MDA $(P<0.05)$ in contrast with the control group. In the $3^{\text {rd }}$ group that was treated with both, the values of studied antioxidants tend to amplify toward the control level but considerably significantly $(P<0.05)$ differ from the control level (Table 1).

\subsection{Histological Investigation}

Liver sections from control and Vit E treated mice delineated normal hepatic cells and the central vein forming the lobular architecture; hepatocytes appeared with vesicular rounded central nuclei, larger nuclei called karyomegaly were observed in the Vit $\mathrm{E}$ group. The cytoplasm became more basophilic in Vit $\mathrm{E}$ treated group with a prominence of kupffer cell nuclei (Plate 1 - No. 1\&2), with TZ induced there was a marked histopathological lesion which was characterized by swollen vacuolated hepatocytes and hyaline material deposited between hepatic cords and enlarged nuclei (karyomegaly) in numerous cells (Plate 1 - No. 3). Liver sections from mice received $\mathrm{TZ}+\mathrm{Vit} \mathrm{E}$ delineated potential improvement in 
hepatic tissue architecture with regular hepatic cords and most hepatocytes showed normal features with rounded central vesicular nuclei. Still few cells showed increased lipid droplets and lacking nuclei and sinusoidal lumen showed prominent kupffer cells nuclei ((Plate 1 - No. 4).

Table 1. Antioxidant status of control and experimental groups

\begin{tabular}{|c|c|c|c|c|}
\hline Antioxidant & Control & Vit E & TZ & TZ +Vit E \\
\hline GSH $(\mu \mathrm{g} / \mathrm{ml})$ & $8.39 \pm 0.21$ & $9.14 \pm 0.41^{\star}$ & $3.30 \pm 0.37^{* *}$ & $4.72 \pm 0.26^{* *}$ \\
\hline GST $(\mathrm{ng} / \mathrm{ml})$ & $0.67 \pm 0.02$ & $0.69 \pm 0.02$ & $0.31 \pm 0.01^{* *}$ & $0.36 \pm 0.042^{* *}$ \\
\hline SOD $(\mathrm{U} / \mathrm{ml})$ & $40.37 \pm 0.56$ & $42.41 \pm 1.92^{\star}$ & $20.79 \pm 0.99^{* *}$ & $26.72 \pm 0.89^{* *}$ \\
\hline $\mathrm{CAT}(\mathrm{ng} / \mathrm{ml})$ & $61.14 \pm 1.21$ & $66.57 \pm 1.72^{\star}$ & $41.11 \pm 1.26^{* *}$ & $46.99 \pm 2.20^{* *}$ \\
\hline $\mathrm{MDA}(\mathrm{ng} / \mathrm{ml})$ & $44.7 \pm 3.73$ & $25.43 \pm 1.17^{* *}$ & $86.14 \pm 1.46^{\star *}$ & $34.86 \pm 1.35^{* *}$ \\
\hline
\end{tabular}

Values are represented as mean \pm standard error. GSH: reduced glutathione, GST: glutathione S-transferase, SOD: superoxide dismutase, CAT: catalase, and MDA: malondialdehyde. The symbols ${ }^{*} P<0.05,{ }^{*}: P<0.01$ indicate significant differences.
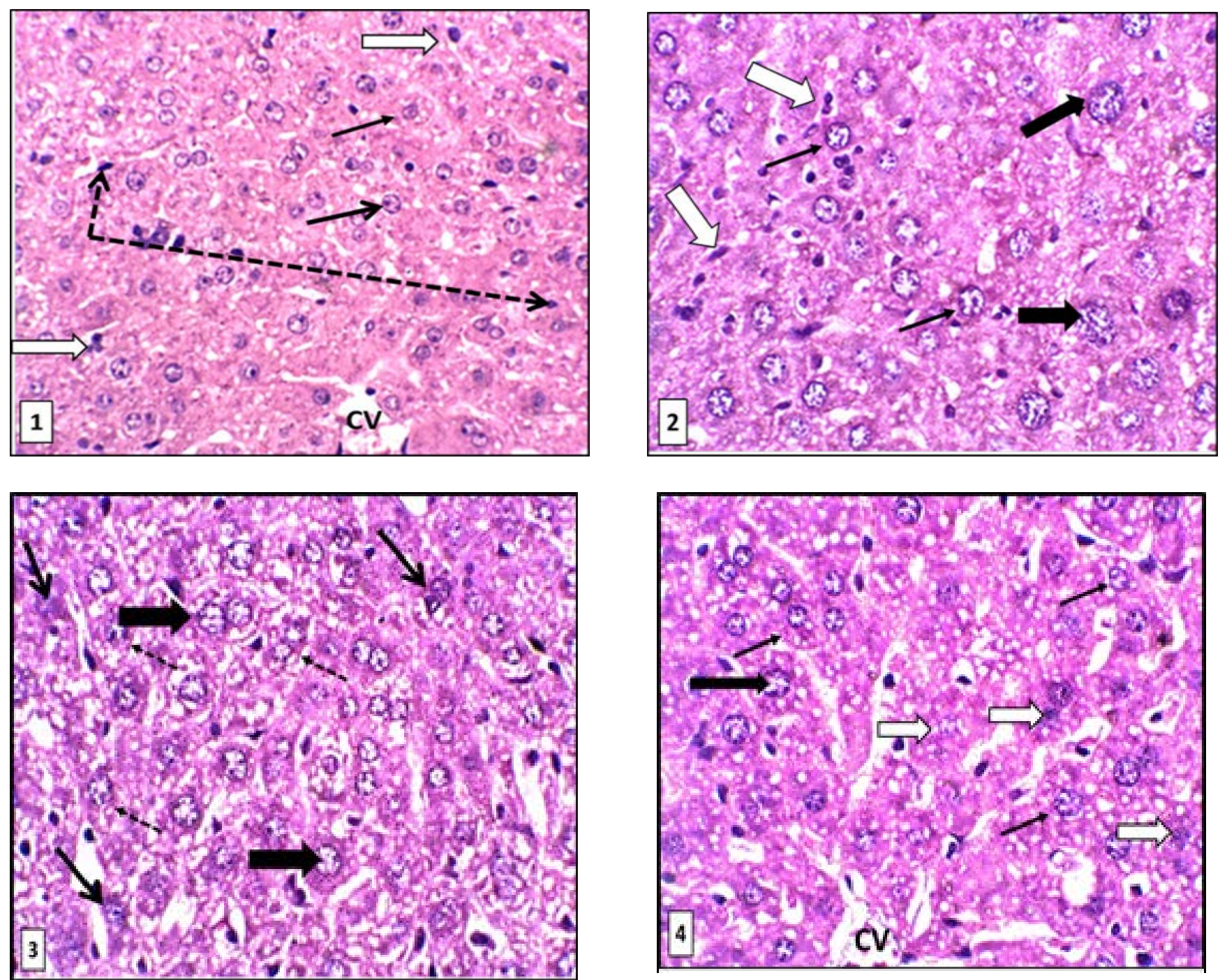

Plate 1: Photomicrographs of control mouse liver (Plate 1 - No. 1), showing, normal hepatocytes (arrow) central vein (CV) and blood sinusoids delineated normal hepatic cells (arrow) blood sinusoids are lined with endothelial cells (dotted arrows), rounded vesicular nuclei (black arrows) within acidophilic cytoplasm with fine tiny lipid droplets 
with occasionally prominent kupffer cell nuclei (white arrows). No. 2 - Vit E treated mouse showing hepatic tissue, some cells showed karyomegaly nuclei (thick black arrows), more basophilic cytoplasm preserved cytoplasm (blacks arrows) and prominent nuclei of Von kupffer cells (white arrows). No. 3: Photomicrograph of liver section from mouse received $\mathrm{TZ}$ showing swollen vacuolated hepatocytes, hyaline cast between the hepatic cords, and many scattered hepatocytes with degenerated pyknotic nuclei and dark cytoplasm (thin black arrows) and karyomegaly (thick black arrow). No. 4: liver section from mouse received $\mathrm{TZ}+\mathrm{Vit} \mathrm{E}$ showed slightly improved architecture of the hepatic tissue with regular hepatic cords, active vesicular nuclei (thin black arrows) that still have shown degenerative changes and pyknotic nuclei (white arrows) or karyomegaly (thick black arrow) (H-E, X 400).

\subsection{Immunohistochemical Studies of COX-2 Expression}

Immunostaining was achieved here to show the involvement of COX-2 in the hepatic toxicity induced by exposure to TZ. Compared to mild COX-2 expression observed in the lining epithelium of hepatic sinusoids of the control group and few degenerated hepatocytes in VitE group hepatocytes (Plate 2 - No. 5\&6), the administration of TZ for 28 days showed up-regulated COX-2 expression in both sinusoidal lining and degenerated hepatocytes (Plate 2 - No. 7). On the other hand, liver sections from mice received $\mathrm{TZ}+\mathrm{Vit} \mathrm{E}$ showed a highly evident decrease in immune-expression of COX-2 in hepatic cords sinusoids and hepatocytes compared with the untreated group (Plate 2 - No. 8).
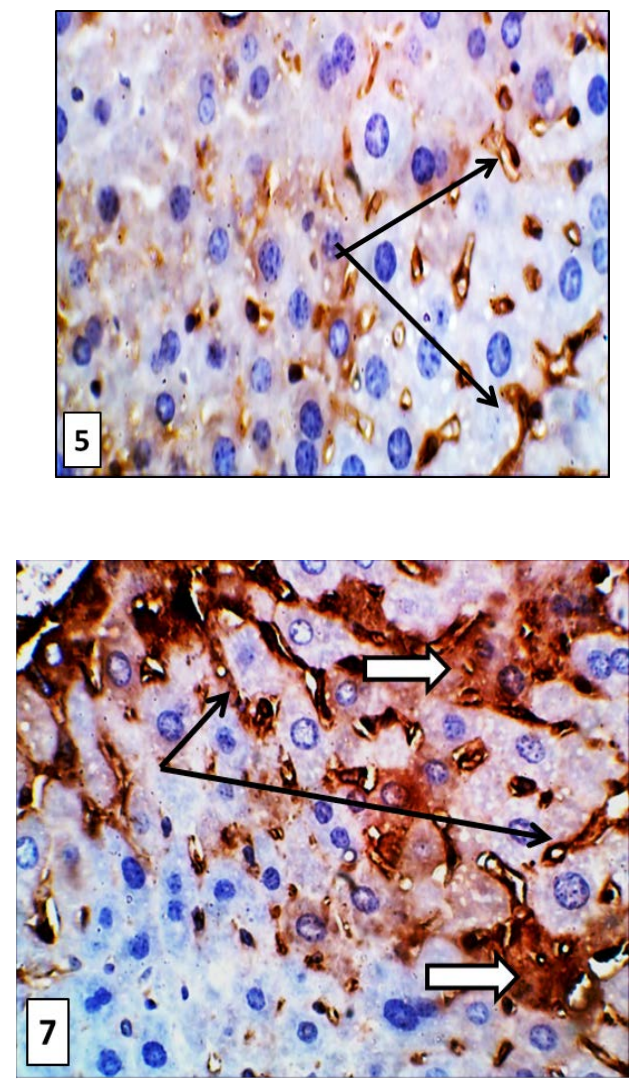
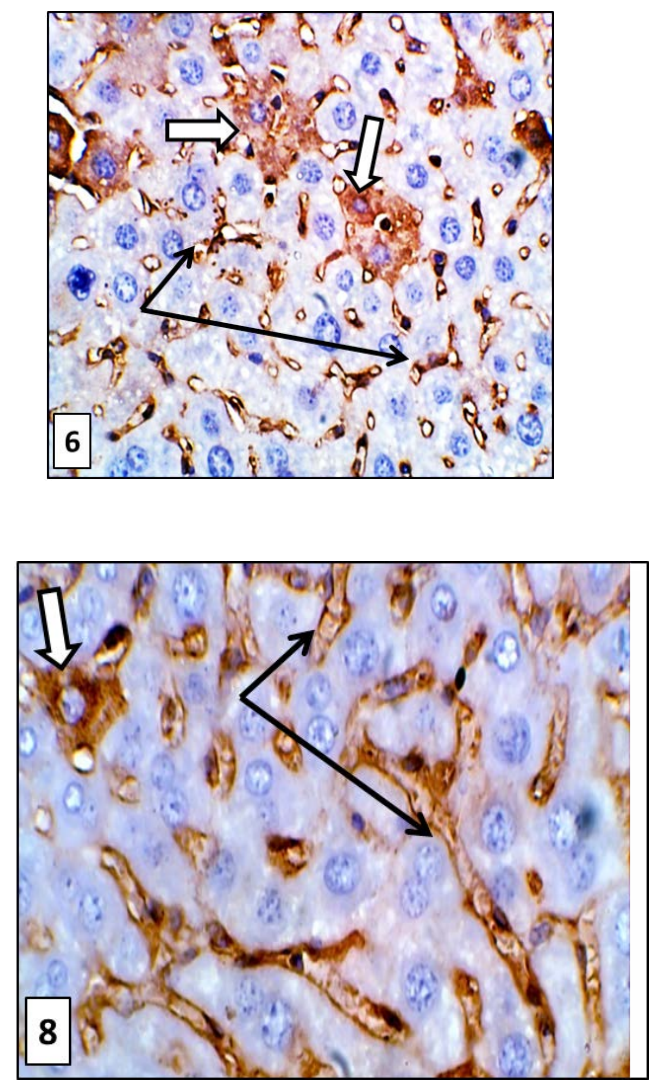

Plate 2: Photomicrograph of liver section from a control mouse (No. 5) showing COX-2 immuno-expression along the lining epithelium of hepatic blood sinusoids (arrows). Hepatocytes showed no or weak staining; No. 6: liver section from Vit E treated mouse showing normal COX-2 immuno- expression in sinusoidal lining cells (black arrows), and the cytoplasm of few hepatocytes with small, degenerated nuclei (white arrows). No. 7: liver section from mouse received TZ for 28 days showing increased immuno-expression of COX-2 in near the central vein (black arrows) and the cytoplasm of 
some hepatocytes (white arrows); No. 8: liver section from mouse received $\mathrm{TZ}+\mathrm{Vit} \mathrm{E}$ showing potential decrease expression of COX-2 (black arrows and white arrows) (COX-2 Immunostaining, X400).

\section{Discussion}

Today the use of food colorants in both food products, domestic cooking, and in a variety of non-food applications has been growing extensively. As licensed by using authorized European Food and Safety Authority $(\text { EFSA })^{19}$ and Food and Drug Administration (FDA $)^{20}$, the meal colorants are produced in many thousand tons/year. In lines with this institution, contemporary typing out techniques proven the poisonous consequences of some of these food supplies and lengthy phrases ${ }^{21}$. Moreover, Attention deficit hyperactivity disorder is the most common, with six synthetic food colorants including TZ (E102). The existing study investigates the hepatic risk of TZ daily administration for 28 consecutive days at 300 $\mathrm{mg} / \mathrm{kg}$ for mice and to realize the protecting function of vitamin $\mathrm{E}$ towards recorded hepatic toxicity by examining liver functions, oxidative stress markers, as well as hepatic immunological and histological changes.

Based on the observations of this study, oral administration of $\mathrm{TZ}$ for 28 days led to an increase in serum levels of liver enzymes (AST, ALT, and ALP) extra than twice instances as in contrast to the control level. Besides, there were decreases in antioxidant parameters (GSH, SOD, GST, and CAT) and increased in oxidative stress as MDA. Moreover, both hepatic immunohistochemical research of COX-2 expression and histological structures had been notably altered, supplementation with Vitamin E partly protected against the recorded hepatic biochemical and histological changes caused by exposure to $300 \mathrm{mg} / \mathrm{kg}$ of TZ. The findings of this study were consistent with the results of different researches that postulated physiological and biochemical $^{22}$, immunological ${ }^{23}$ and histological ${ }^{24}$, severe changes in the liver after administration of tartrazine. Moreover, as reported by Demirkol, et al. ${ }^{25}$ reported the a dministration of tartrazine at the dose of $7.5 \mathrm{mg} / \mathrm{kg}$ daily for 30 days lead to an extreme histopathological and cellular change of rat liver. In the existing study, the prolonged exposure to the tested dose level of TZ has delivered histological changes characterized by congested and dilated portal veins, degeneration in hepatic cells, and apoptosis.

Although the exact mechanisms of TZ toxicity are now not wholly elucidated, preceding research indicated that reactive oxygen species and antioxidant imbalance is the principal toxicity causes. As postulated, oxidative stress may take place due to increased ROS production, a drop of antioxidant mechanisms, or both ${ }^{10,25}$. In the current study, the increased levels of malondialdehyde which is the end product of lipid peroxidation, and decreased activities of redox enzymes (GSH, SOD, GST, and CAT) indicate oxidative stress imbalance in TZ-intoxicated mice. These results were in accordance with the data reported by Dermirkol, et al. ${ }^{26}$ and Abdel-Aziz, et al. ${ }^{27}$. Previous studies had pointed out the role of aromatic amines produced in the course of azo dyes metabolism and manufacturing of aromatic amines. Otherwise, TZ seems to be metabolized by using way of gastrointestinal microflora to sulfanilic acid and $\alpha$-amino- $\beta$-keto butyric acid which absorbed and induced different harmful physiological and histological body effects ${ }^{28}$. The described hypothesis, however, is supported as aromatic amines have been identified in the urine of experimental animals ${ }^{29}$, reduction of intestinal microbiota $^{10}$, and accelerated Reactive Oxygen Species $(\mathrm{ROS})^{10}$, after treatments of experimental animals with distinctive doses of azo dye. Our results brought delivered assist to preceding research studies by suggesting reactive oxygen species role in mediating TZ toxicity and proven oxidative stress to body tissue and diminished hepatic tissue functions and structure.

Next, this study evaluated TZ impact on immune system function. This study demonstrates that ingestion of $\mathrm{TZ}$ at the dose of $300 \mathrm{mg} / \mathrm{kg}$ alters the humoral immune response in male mice. The effects confirmed clear immunosuppressive effects recorded as elevated COX-2 in hepatic sinusoidal lining cells and cytoplasm of some hepatocytes. This investigation is in accordance with different studies conducted that TZ-treated animals displayed a significant upward thrust of immunohistochemical localization of hepatic fibrotic markers collagen 1- $\alpha$, transforming growth factor $\beta-1$, fibronectin, and apoptotic marker as caspase- $3^{30,31}$.

Cyclooxygenase- 2 is an inducible form of the enzyme that catalyzes the first step in the synthesis of prostaglandins, inflammatory diseases, carcinogenesis, and resistance to apoptosis $^{32,33}$. Meanwhile, COX-2 performs imperative passion for well-known cytotoxic therapy. The accelerated activity, however, used to be the innate and adaptive 
immune response. COX-inhibitors facilitate the patients to achieve threat associated with multiple risks of hepatic toxicity as the result of prolonged $\mathrm{TZ}$ administration. As suggested via Ricciotti and FitzGerald ${ }^{34}$, a variety of extracellular and intracellular stimuli result in COX-2 expression in many cell types. Martín-Sanz, et al..$^{35}$, state that evaluation of COX-2 in hepatic cells contribution to the onset of hepatic dysfunctions. Different researchers have determined inflammation but no carcinogenetic lesions in exceptional types of organs that include the liver as a result of TZ toxicity ${ }^{36}$. However, hepatocytes express COX-2 after TZ inflammation usually associated with increased in inflammation- responsive cells as Kupffer cells and macrophages. Elevation of COX-2 in hepatocytes after TZ exposure constitutes physiological situations best for evaluating the function of prostaglandins in liver pathogenesis. Finally, the data from COX-2 trans genesis in hepatocytes support the idea that by itself, COX-2 seems no longer to contribute to tumors improvement in experimental animals.

The existing study additionally examined the impact of treatment with vitamin $\mathrm{E}$ on $\mathrm{TZ}$ prompted hepatic toxicity in mice. The information recorded confirmed ameliorating practicable of all the studied biochemical and histological parameters. From the current data, it is apparent that treating TZ-intoxicated mice with vitamin appreciably improved GSH. GST, and CAT, and diminished AST, ALT, and ALP in contrast to TZ handled group. These observations are in accordance with Al-Seeni, et al..$^{37}$, Balta, et al..$^{38}$, and Ahmad, et al. ${ }^{39}$, which verified that vitamin $\mathrm{E}$ therapy may additionally in part effective in lowering hepatic functional and histological changes related to chronic hepatic failure produced by acute $\mathrm{TZ}$ toxicity. According to $\mathrm{Al}-\mathrm{Attar}^{40}$. reductions in the impaired lipid peroxidation due to $\mathrm{TZ}$ toxicity may additionally be an important aspect in the action of vitamin E. Also, vitamin E should be beneficial to protect membrane-lipids as mentioned by Raederstorff, et al. ${ }^{41}$ Daniel and, notably, to prevent protein oxidation produced through intoxication ${ }^{42}$. Tocopherol is one of the most necessary and indispensable lipid-soluble antioxidants. It protects cell membranes from oxidation through reacting with lipid radicals produced in the lipid peroxidation chain response ${ }^{43}$. This would remove the free radical intermediates and prevent the oxidation response from continuing.

\section{Conclusions}

From this experimental study, it can be concluded that daily administration of tartrazine at dose of $300 \mathrm{mg} /$ $\mathrm{kg}$ for 28 days had hepatotoxic as resulted in damage of liver structures and significantly affected the activities of serum AST, ALT and ALP and decreased activities of redox enzymes (GSH, SOD, GST, and CAT). Moreover, both hepatic immunohistochemical COX-2 and hepatic cellular structure were changed. The pre-treatment with Vitamin $\mathrm{E}$ before $\mathrm{TZ}$ administration reduced the degree of oxidative stress, although this vitamin produced only slight changes in the hepatic injury.

\section{Acknowledgements}

The author wish to acknowledge Prof. Sayed Rawi University of Jeddah, and Prof. Amal A. E. Ibrahim, Faculty of Science for Girls, Northern Border University, Ar'ar, KSA, for their great help in this study.

\section{References}

1. Martins N, Roriz CL, Morales P, Barros L, Ferreira IC. Food colorants: Challenges, opportunities and current desires of agro-industries to ensure consumer expectations and regulatory practices. Trends in Food Science and Technology. 2016; 52:1-15. http://www.sciencedirect.com/science/journal/09242244. https://doi.org/10.1016/j.tifs.2016.03.009.

2. Sigurdson GT, Tang P, Giusti MM. Natural colorants: Food colorants from natural sources. Annual Review of Food Science and Technology. 2017; 8:261-280. https:// doi.org/10.1146/annurev-food-030216-025923. PMid: 28125346.

3. Cong Y, Han X, Wang Y, Chen Z, Lu Y, Liu T, et al. Drug toxicity evaluation based on organ-on-a-chip technology: A Review. Micromachines. 2020; 11(4):381. doi: 10.3390/ mi11040381. https://doi.org/10.3390/mi11040381. PMid: 32260191, PMCid: PMC7230535.

4. Tan NC, Van Leeuwen A, Van Voorthuizen EM, Slenders P, Prenafeta-Boldu FX, Temmink H, et al. Fate and biodegradability of sulfonated aromatic amines. Biodegradation. 2005; 16(6):527-537. https://doi.org/10.1007/s10532-0046593-x. PMid: 15865345.

5. Skipper PL, Kim MY, Sun H-LP, Wogan GN, Tannenbaum SR. Monocyclic aromatic amines as potential human carcinogens: Old is new again. Carcinogenesis. 2010; 31(1):50-58. https://doi.org/10.1093/carcin/bgp267. PMid: 19887514, PMCid: PMC2802674. 
6. Amin KA, Al-Shehri FS. Toxicological and safety assessment of tartrazine as a synthetic food additive on health biomarkers: A review. African Journal of Biotechnology. 2018; 17(6):139-149. https://doi.org/10.5897/AJB2017.16300.

7. Skovgaard N. Safety evaluation of certain food additives and contaminants. International Journal of Food Microbiology. 2000; 62(1-2):165-166. https://doi.org/10.1016/S01681605(00)00409-8.

8. Cemek M, Büyükokuroğlu ME, Sertkaya F, Alpdağtaş S, Hazini A, Önül A, et al. Effects of food color additives on antioxidant functions and bioelement contents of liver, kidney and brain tissues in rats. J. Food Nutr. Res. 2014; 2(10):686-691. https://doi.org/10.12691/jfnr-2-10-6.

9. Phillips $\mathrm{M}$, Cataneo R, Greenberg J, Grodman R, Gunawardena R, Naidu A. Effect of oxygen on breath markers of oxidative stress. European Respiratory Journal. 2003; 21(1):48-51. https://doi.org/10.1183/09031936.02.00 053402. PMid: 12570108.

10. Albasher G, Maashi N, Alfarraj S, Almeer R, Albrahim T, Alotibi F, et al. Perinatal exposure to tartrazine triggers oxidative stress and neurobehavioral alterations in mice offspring. Antioxidants. 2020; 9(1):53. https://doi. org/10.3390/antiox9010053. PMid: 31936188, PMCid: PMC7023231.

11. Miller III ER, Pastor-Barriuso R, Dalal D, Riemersma RA, Appel LJ, Guallar E. Meta-analysis: High-dosage vitamin E supplementation may increase all-cause mortality. Annals of Internal Medicine. 2005; 142(1):37-46. https://doi. org/10.7326/0003-4819-142-1-200501040-00110. PMid: 15537682.

12. Lippman SM, Klein EA, Goodman PJ, Lucia MS, Thompson IM, Ford LG, et al. Effect of selenium and vitamin $\mathrm{E}$ on risk of prostate cancer and other cancers: The Selenium and Vitamin E Cancer Prevention Trial (SELECT). Jama. 2009; 301(1):39-51. https://doi.org/10.1001/jama.2008.864. PMid: 19066370, PMCid: PMC3682779.

13. Bassey IE, Gali RM, Udoh AE. Fertility hormones and vitamin $\mathrm{E}$ in active and passive adult male smokers in Calabar, Nigeria. PloS One. 2018; 13(11):e0206504. https://doi.org/10.1371/journal.pone.0206504. PMid: 30399168, PMCid: PMC6219777.

14. Muller D. Vitamin E-its role in neurological function. Postgraduate Medical Journal. 1986; 62(724):107-112. https://doi.org/10.1136/pgmj.62.724.107. PMid: 3540925, PMCid: PMC2418603.

15. Lee I-M, Cook NR, Gaziano JM, Gordon D, Ridker PM, Manson JE, et al. Vitamin E in the primary prevention of cardiovascular disease and cancer: The Women's Health Study: A randomized controlled trial. Jama. 2005; 294(1):56-65. https://doi.org/10.1001/jama.294.1.56. PMid: 15998891.
16. Pavithra D, Praveen D, Chowdary PR, Aanandhi MV. A review on role of Vitamin E supplementation in type 2 diabetes mellitus. Drug Invent Today. 2018; 10(2):236-240.

17. Olfert ED, Cross BM, McWilliam AA. Guide to the care and use of experimental animals: Canadian Council on Animal Care Ottawa; 1993.

18. Badgujar PC, Pawar NN, Chandratre GA, Telang A, Sharma A. Fipronil induced oxidative stress in kidney and brain of mice: Protective effect of vitamin E and vitamin C. Pesticide Biochemistry and Physiology. 2015; 118:10-18. https://doi. org/10.1016/j.pestbp.2014.10.013. PMid: 25752424.

19. Food U, Administration D. Overview of food ingredients, additives \& colors. Retrieved March. 2013; 21:2013.

20. Amchova P, Kotolova H, Ruda-Kucerova J. Health safety issues of synthetic food colorants. Regulatory Toxicology and Pharmacology. 2015; 73(3):914-922. https://doi.org/10.1016/j.yrtph.2015.09.026. PMid: 26404013.

21. Carocho M, Barreiro MF, Morales P, Ferreira IC. Adding molecules to food, pros and cons: A review on synthetic and natural food additives. Comprehensive Reviews in Food Science and Food Safety. 2014; 13(4):377-399. https:// doi.org/10.1111/1541-4337.12065.

22. Elekima I, Nwachuku OE. Evaluation of Acute and Chronic Toxicity of Tartrazine (E102) on Steriod Reproductive Hormones of Albino Rats. Asian Journal of Research and Reports in Endocrinology. 2019:1-15. http://www.sdiarticle3.com/review. https://doi.org/10.9734/ajrb/2019/ v5i130083.

23. Arefin S, Hossain MS, Akter Neshe S, Rashid M, Or M, Amin MT, et al. Tartrazine induced changes in physiological and biochemical parameters in Swiss albino mice. Mus Musculus. 2017. https://doi.org/10.12991/marupj.319304.

24. Khayyat L, Essawy A, Sorour J, Soffar A. Tartrazine induces structural and functional aberrations and genotoxic effects in vivo. Peer. J. 2017; 5:e3041. https://doi.org/10.7717/ peerj.3041. PMid: 28243541, PMCid: PMC5326541.

25. Demirkol O, Zhang $X$, Ercal N. Oxidative effects of Tartrazine (CAS No. 1934-21-0) and New Coccin (CAS No. 2611-82-7) azo dyes on CHO cells. Journal für Verbraucherschutz und Lebensmittelsicherheit. 2012; 7(3):229-236. https://doi.org/10.1007/s00003-012-0782-z.

26. Dermirkol O, Zhang X, Ercal N. Oxidative effect of tartrazine (Cas No. 1934-21-0) and new coccin (Cas No. 2611-82-7) azo dyes on CHO cells. Journal of Consumer Protection and Food Safety. 2012; 7:229-236. https://doi. org/10.1007/s00003-012-0782-z.

27. Abdel-Aziz H, Alazouny Z, Abdelfadee K, Abohashem A. Effect of tartrazine on thyroid gland of male rat and ameliorating role of curcumin (histological and immunohistochemical study). J Biochem Cell Biol. 2019; 2(111):2. 
28. Pestana S, Moreira M, Olej B. Safety of ingestion of yellow tartrazine by double-blind placebo controlled challenge in 26 atopic adults. Allergologia et Immunopathologia. 2010; 38(3):142-146. https://doi.org/10.1016/j.aller.2009.09.009. PMid: 20106580.

29. Sreedharan V, Rao KVB. Biodegradation of Textile Azo Dyes. Nanoscience and Biotechnology for Environmental Applications: Springer; 2019. p. 115-139. https://doi. org/10.1007/978-3-319-97922-9_5.

30. Abd-Elhakim YM, Moustafa GG, Hashem MM, Ali HA, Abo-EL-Sooud K, El-Metwally AE. Influence of the long-term exposure to tartrazine and chlorophyll on the fibrogenic signalling pathway in liver and kidney of rats: The expression patterns of collagen $1-\alpha$, TGF $\beta$ - 1 , fibronectin, and caspase-3 genes. Environmental Science and Pollution Research. 2019; 26(12):12368-12378. https://doi. org/10.1007/s11356-019-04734-w. PMid: 30847814.

31. Abd-Elhakim YM, Hashem MM, El-Metwally AE, Anwar A, Abo-EL-Sooud K, Moustafa GG, et al. Comparative haemato-immunotoxic impacts of long-term exposure to tartrazine and chlorophyll in rats. International Immunopharmacology. 2018; 63:145-154. https://doi. org/10.1016/j.intimp.2018.08.002. PMid: 30096597.

32. Desai SJ, Prickril B, Rasooly A. Mechanisms of phytonutrient modulation of cyclooxygenase-2 (COX-2) and inflammation related to cancer. Nutrition and Cancer. 2018; 70(3):350-375. https://doi.org/10.1080/01635581.201 8.1446091. PMid: 29578814, PMCid: PMC6309701.

33. Hidalgo-Estévez AM, Stamatakis K, Jiménez-Martínez M, López-Pérez R, Fresno M. Cyclooxygenase 2-regulated genes an alternative avenue to the development of new therapeutic drugs for colorectal cancer. Frontiers in Pharmacology. 2020; 11. https://doi.org/10.3389/ fphar.2020.00533. PMid: 32410997, PMCid: PMC7201075.

34. Ricciotti E, FitzGerald GA. Prostaglandins and inflammation. Arteriosclerosis, Thrombosis, and Vascular Biology. 2011; 31(5):986-1000. https://doi.org/10.1161/ ATVBAHA.110.207449. PMid: 21508345, PMCid: PMC3081099.

35. Martín-Sanz P, Casado M, Boscá L. Cyclooxygenase 2 in liver dysfunction and carcinogenesis: Facts and perspectives. World Journal of Gastroenterology. 2017;23(20):3572. https://doi.org/10.3748/wjg.v23.i20.3572. PMid: 28611510, PMCid: PMC5449414.
36. Martín-Sanz P, Mayoral R, Casado M, Boscá L. COX-2 in liver, from regeneration to hepatocarcinogenesis: What we have learned from animal models? World Journal of Gastroenterology: WJG. 2010; 16(12):1430. https://doi. org/10.3748/wjg.v16.i12.1430. PMid: 20333781, PMCid: PMC2846246.

37. Al-Seeni MN, El Rabey HA, Al-Hamed AM, Zamazami MA. Nigella sativa oil protects against tartrazine toxicity in male rats. Toxicology Reports. 2018; 5:146-155. https:// doi.org/10.1016/j.toxrep.2017.12.022. PMid: 29854586, PMCid: PMC5977377.

38. Balta I, Sevastre B, Mireşan V, Taulescu M, Raducu C, Longodor AL, et al. Protective effect of blackthorn fruits (Prunus spinosa) against tartrazine toxicity development in albino Wistar rats. BMC Chemistry. 2019; 13(1):104. https://doi.org/10.1186/s13065-019-0610-y. PMid: 31417987, PMCid: PMC6688354.

39. Ahmad Z, Hussain R, Riaz M, Khan MA, Nadeem M, Akram K, et al. Mitigation of toxic effects caused by tartrazine in wistar rats through oral administration of melon seed oil. Pak. J. Agri. Sci. 2019; 56(2):435-442. https://doi. org/10.21162/PAKJAS/19.6782

40. Al-Attar AM. Antioxidant effect of vitamin E treatment on some heavy metals-induced renal and testicular injuries in male mice. Saudi Journal of Biological Sciences. 2011; 18(1):63-72. https://doi.org/10.1016/j.sjbs.2010.10.004. PMid: 23961105 , PMCid: PMC3730955.

41. Raederstorff D, Wyss A, Calder PC, Weber P, Eggersdorfer M. Vitamin $\mathrm{E}$ function and requirements in relation to PUFA. British Journal of Nutrition. 2015; 114(8):11131122. https://doi.org/10.1017/S000711451500272X. PMid: 26291567, PMCid: PMC4594047.

42. Rendón-Ramirez A, Cerbón-Solórzano J, Maldonado-Vega M, Quintanar-Escorza M, Calderón-Salinas J. Vitamin-E reduces the oxidative damage on $\delta$-aminolevulinic dehydratase induced by lead intoxication in rat erythrocytes. Toxicology in Vitro. 2007; 21(6):1121-1126. https://doi. org/10.1016/j.tiv.2007.04.019. PMid: 17572058.

43. Olszowy M. What is responsible for antioxidant properties of polyphenolic compounds from plants? Plant Physiology and Biochemistry. 2019; 144:135-143. https://doi.org/10.1016/j.plaphy.2019.09.039. PMid: 31563754 . 